\title{
Cohabitation and premarital sex amongst Christian youth in South Africa today: A missional reflection
}

\author{
Author: \\ Thinandavha D. Mashau ${ }^{1}$ \\ Affiliation: \\ ${ }^{1}$ Department of Missiology, \\ North-West University, \\ Potchefstroom Campus, \\ South Africa \\ Note: \\ This article is published \\ in the Section Practical \\ Theology of the Society for \\ Practical Theology in \\ South Africa.

\section{Correspondence to:} \\ Derrick Mashau \\ Email: \\ 10898328@nwu.ac.za \\ Postal address: \\ PO Box 20004, Noordbrug \\ 2522, South Africa \\ Dates: \\ Received: 22 June 2010 \\ Accepted: 24 Mar. 2011 \\ Published: 02 Aug. 2011 \\ How to cite this article: \\ Mashau, T.D., 2011, \\ 'Cohabitation and \\ premarital sex amongst \\ Christian youth in South \\ Africa today: A missional \\ reflection', HTS Teologiese \\ Studies/Theological Studies \\ 67(2), Art. \#899, 7 pages. \\ doi:10.4102/hts.v67i2.899
}

(C) 2011. The Authors. Licensee: AOSIS OpenJournals. This work is licensed under the Creative Commons Attribution License.
This article explored the rising trends of cohabitation and premarital sex amongst Christian and non-Christian youth in South Africa that is becoming more socially acceptable. Moving from a premise of engaging in these practices, which is not biblically justified, to what a missional Christian church can do, this article sought to bring the numbers of those who cohabit and engage in premarital sex down. The thesis of this article was that a missional church should view cohabitation and premarital sex as frontiers that need to be crossed to save the lives of our youth by minimising premarital pregnancies and the spread of sexually transmitted diseases (the Human immunodeficiency virus [HIV] and Acquired immune deficiency syndrome [AIDS] pandemic included). This will also go a long way in saving the sinking image of marriage. It is the presupposition of this article that cohabitation and premarital sex are great threats to the institution of marriage.

\section{Introduction}

Human culture in the 21st century has been transformed by a revolution in sexual values. Promiscuity is regarded by many as a virtue to pursue. Children who do not engage in premarital sex are perceived by their peers as stupid, boring and unsophisticated, with the result that children are trying sex at earlier ages than ever before (Mashau 2008:30). This has given birth to a culture of cohabitation, where since the 1960s cohabitation and premarital sex have been growing trends worldwide (Scherrer \& Klepacki 2004:134; cf. Musick 2007:251). Cohabitation and premarital sex as a lifestyle are on the rise throughout the world and South Africa is no exception. They are fast becoming a kind of a norm amongst students and the working youth, who not only choose to share their lodgings, but also their blankets (see Dolbik-Vorobei 2005; cf. Murray-Swant 2005).

These growing trends are also creeping into the church and it has become a subject of concern for two reasons. Firstly, marriage as an institution, as traditionally and biblically understood, is under enormous strain because of the growing trends of cohabitation and premarital sex amongst both Christian and non-Christian youth. Secondly, the teaching of the church about premarital abstinence as a norm amongst Christian youth is also under severe attack; this has prompted various responses from the global church regarding the manner in which these trends should be dealt with. Whilst the Church of England accepts cohabitation as a step towards marriage (Thatcher 1999:105), other church traditions differ profoundly from this view. Some of these differences are captured in the following words:

The Roman Catholic Church treats cohabitation under the rubric of 'free unions', and condemns those, along with adultery, divorce, polygamy and incest as 'grave offences against the dignity of marriage'. Orthodox churches are authoritatively said to be unprepared even to raise 'the question of sexual activity outside of marriage', and the same response is generally made by evangelical churches and their members.

(Thatcher 1999:105)

It is clear from the foregoing that these different standpoints on the side of different church traditions are doing more harm than good, because it is sending mixed messages to the world. There is need for a missional approach on the side of the church in this regard and only a missional church can succeed in developing a clear biblical message regarding cohabitation and premarital sex amongst the youth in South Africa today. The phrase 'missional church' is used in this context to refer to those churches that seek to remain true to the missio Dei [mission of God] by not only identifying cohabitation and premarital sex amongst the youth as missionary frontiers to be crossed, but also by devising practical strategies to help bring down numbers of those who engage in such practices. The overarching question of this article is: What can a missional church do to bring the numbers of those who cohabit and engage in premarital sex down in this generation? In order to answer this question, this article will define cohabitation and premarital sex by looking at these concepts within the South Africa context; outlining cohabitation and premarital sex in South Africa, biblical perspectives regarding human sexuality and the implications for cohabitation and premarital sex, as well as practical guidelines regarding 
what a missional church can do to bring down the numbers of South African youth who are cohabiting and engaging in premarital sex.

\section{Towards a working definition of cohabitation and premarital sex Defining cohabitation}

Defining the word cohabitation is very complex, but it is generally used to describe the relationship between unmarried couples who live together as husband and wife (Parry 1981:1; cf. De Bruyn 1993:156). According to this definition, cohabitation is more a testing ground for marriage, or a step on the way to marriage, much like dating and engagement. Schwellnus (1994:1), on the other hand, uses the term cohabitation in a broader sense to denote a situation in which two people live together in a family framework analogous to marriage, without actually having gone through a ceremony of marriage. These two definitions differ profoundly, in that the latter used the phrase 'two people' instead of 'husband and wife', which was used in the former. The term cohabitation is used in the latter instance to include people of the same sex living together in a stable, exclusive relationship; however, cohabitation should be distinguished from the nonsexual relationship of a brother and a sister who are living together (Schwellnus 1994:1) and occasional sexual relationships between men and women living together in a commune (De Bruyn 1993:206).

The content of a cohabitational relationship entails consensual premarital sex between the couple and a sense of responsibility towards each other (Schwellnus 1994:12). Some people use cohabitation as a stepping-stone to marriage, whilst others prefer to cohabit for as long as they live (Manning et al. 2007:559). In the end, a distinction can be made between three types of cohabitation, namely (Thatcher 1999:104):

- 'temporary or casual cohabitation', entered into with little thought or commitment

- conscious preparation for marriage or 'trial marriage'

- cohabitation as a substitute for marriage either because the couple is opposed to marriage as an institution, or because they live in a society where cohabitation is an institution already.

Cohabitation is used in this article to define a consensual relationship between a man and a woman who decides to live together as husband and wife and who are having regular sexual intercourse without having married.

\section{Defining premarital sex}

Premarital sex is sexual intercourse engaged in by a person or persons who are not yet married. It is generally used in reference to young people who are presumed to be of marriageable age, or will one day be married, but who are engaging in sexual practices prior to their being sanctioned within a marriage. Their sexual relationship should be placed in the category of premarital sex, because they are having sexual intercourse before marriage. This is in line with the traditional Christian sexual ethic, which maintains that sexual intercourse is to be reserved for marriage, specifically monogamous marriage. The word premarital sex is therefore used in this article to define the act of engaging in sexual intercourse before marriage. The word fornication can also be used interchangeably for this act. Having defined cohabitation and premarital sex, we now move on to outline the two trends within the South African context.

\section{Cohabitation and premarital sex in South Africa}

The incidence of cohabitation is increasing in South Africa and around the world on a daily basis. It has become more common and more socially acceptable in South Africa for couples to live together without being married. For the purpose of this article, we will look closely at the prevalence and dynamics of cohabitation and premarital sex in South Africa and also reflect on the whole issue from a legal point of view.

\section{Prevalence of cohabitation and premarital sex in South Africa}

In South Africa, it is generally believed that there is an increasing trend towards cohabitation, although there is little concrete demographic evidence to confirm this. It is difficult to determine the prevalence of cohabitation in South Africa, because statistics do not provide conclusive evidence of this trend, given that information relating to the number of cohabiting couples has been inferred from statistics relating to marriage, divorce, remarriage and illegitimate births. The essence of this is captured in the following words:

For demographics seeking to document trends in marriage and partnering in South Africa, there are surprisingly few sources of data. In a country where marriage is far from universal, the lack of discrimination between marital states and cohabitation arrangements in the most recent South African censuses limits the interest of this data.

(Hosegood, McGrath \& Moultrie 2009:280)

My experience of working with the youth in church and at tertiary institutions attests to the fact that cohabitation and premarital sex are common amongst tertiary and working youth. Mwaba and Naidoo (2005:651) share the same sentiment when they also noted, amongst others, that premarital sex amongst South African university students is on the increase. The growing numbers of those who cohabit and engage in premarital sex are made manifest in the area of high rate premarital pregnancy and the spread of the Human immunodeficiency virus (HIV) and Acquired immune deficiency syndrome (AIDS) pandemic amongst the youth in greater proportions. Parents and churches are often called to deal with these cases more often.

\section{Cohabitation and the South African law}

According to Stern (2006), there is no legislation in South Africa to date that regulates cohabitation. People who 
choose to live together in mutually supportive, long-term relationships without getting married are called cohabitees and certain legal rights that apply to married couples do not automatically apply to them. This is also asserted by Van der Merwe and Du Plessis (2004:158), who also noted, amongst others, that sexual cohabitation has no status in South African law. Gustafsson and Worku (2006:9) further attest that cohabitation in South Africa has no legal bearing in terms of ownership of assets, unless the property is registered under both partners' names; therefore, the legislature has endowed cohabitation with certain legal consequences in a fairly piecemeal and inconsistent manner. Stern (2006) provides the following advice to the cohabitees:

What cohabitees can do is regulate the financial and maintenance aspects of their relationship by entering cohabitation contracts. This would set out how the partners pool their resources, what each partner owns and whether the one will have a financial duty to support the other whilst in the relationship and in the event that the relationship terminates.

(Stern 2006:1)

\section{The dynamics of cohabitation and premarital sex in South Africa}

Cohabitation and premarital sex have reached a point of crisis amongst South African youth. As already noted, they are unquestionably on the rise amongst the working youth and those who are students at tertiary institutions. When looking closely at the dynamics of cohabitation and premarital sex in South Africa, there are three elements that are worth noting, namely the youth in crisis, the factors contributing to cohabitation and premarital sex and the consequences thereof.

\section{Youth in crisis}

The growing trends of cohabitation and premarital sex in South Africa are signs that our youth are in a serious crisis and this manifests itself in a number of ways. According to Mashau (2006:43-44), the following symptoms are indicators of youth in crisis:

- There are a large number of girls engaging in premarital sex who become pregnant in their teens and the majority of them then become school dropouts. These children choose to become sexually active at an early stage of their lives.

- Amongst the majority of African youth, sex before marriage has become a norm, because they maintain that it confirms their freedom. They say they are free to do whatever they please with their bodies; after all, who cares?

- Some are involved in sexual activities before they are married for the sake of gaining self-esteem and to gain popularity amongst their peers.

- There is an increase in the number of teenagers committing suicide because of a failure to cope with pressures related to love, courtship and marriage.

- There is also a high rate of young women exposed to rape and all other forms of abuse against women.
- The majority of our children are even exposed to sexually transmitted infections (STIs) and diseases such as HIV and AIDS because they choose to be sexually active outside marriage. Graveyards receive many of our youth, owing to the massive number of deaths caused by the AIDS pandemic.

\section{Factors contributing to cohabitation and premarital sex}

There are various factors contributing to the crisis that young people are facing in this age. According to Mashau (2006:44-46), factors contributing to the crisis of cohabitation and premarital sex amongst the South African youth include, amongst others, the following:

- Publicity: The media focuses more and more upon the sensual. African youth are exposed to sex and related matters through the medium of newspapers, television, pornographic videos, the internet, radio and various magazines. Explicit sex videos and DVDs are the most popular sellers on the market. They also receive mixed messages from the media. In any given week, they are likely to hear contradictory messages such as 'No sex until you're married', 'No sex until you are older', 'No sex unless you're protected' or 'No sex unless you're in love' (Anderson 2000:16).

- Peer pressure: The majority of young people who become involved in cohabitation and premarital sex do so because of peer pressure. They look at their peers and give in to temptation, because 'everyone does $\mathrm{it}^{\prime}$. They do it in order to avoid being laughed at and to receive affirmation from their peers. In the end, cohabitation and premarital sex have become kinds of passports to acceptance in a particular age group (cf. Mwaba \& Naidoo 2005:651).

- Experimenting with sex: We need to note that there is a growing trend amongst African young people these days to think that it is old-fashioned if they do not experiment with sex before marriage. They think that it is part and parcel of modernity to engage in sex before marriage and want to familiarise themselves with matters concerning sex before they get married. That is why the majority will opt to move in with their girlfriends or boyfriends.

- The reality of $\sin$ in our lives: One of the factors contributing to our youth engaging in cohabitation and premarital sex is the reality of sin in our lives. According to Ephesians 2:1-3, there are three other factors attached to the fall of humanity in Genesis 3 that deserve to be mentioned. The first is the devil himself, who is said to be the great deceiver. The second is the sexual desires within oneself; the temptation to give in to that kind of internal drive is always strong. The third has to do with the influence from the outside, 'the world in its sinful state'. Sin has so blinded us that we no longer want to conduct our lives according to the dictates of the law of God.

- Drug and alcohol abuse: There is a high correlation between alcohol and sexual experiences. A number of African youngsters, especially those coming from rural areas, tend to become involved in drugs and alcohol abuse immediately after they enter tertiary education institutions. It is very difficult for these youth to control 
their sexual drives when they are under the influence of drugs and alcohol.

- The internet: Unguided and uncontrolled surfing on the Internet can expose youth to pornography online. Young people are often hooked by sexual images that they are exposed to as they surf the internet. The internet is also doing a great deal of damage when it comes to the sexual lifestyle of South African youth, because some of those who are bombarded by pornography also like to put it into practice.

- Fashions in clothing: Another factor contributing to the pervasive emphasis on sex amongst the youth in South Africa is fashions in clothing. These days it is difficult to find clothes for teenage girls that are not revealing or tight-fitting. This makes girls more willing to flaunt their bodies and makes them vulnerable to sexual predators that are willing to buy them expensive clothes in exchange for sexual favours.

\section{Consequences of cohabitation and premarital sex}

The majority of our children who engage in sex before marriage are not fully informed about the consequences involved in such actions and those who are aware of the consequences tend to ignore them. South African youth and their peers all over the world should be made aware of the serious consequences of cohabitation and sex outside marriage. Sex before and outside marriage is destructive and might even cause death in some instances (Pr 14:12). Some of the dangers and miseries brought about by cohabitation and sex outside marriage include the following:

- Unwanted and unexpected pregnancy: There are many girls who fall pregnant unexpectedly because they engage in premarital sex (Chitamun \& Finchilescu 2003:154). These unplanned and unwanted pregnancies force many of these children to seek legal or illegal abortions.

- Shotgun weddings: Shotgun weddings might occur as a result of cohabitation and premarital sex as they are forced to take place because of premarital pregnancies. The so-called shotgun wedding tries to make a marriage where none exists (Olthuis 1976:54). The couple is forced to legalise their relationship because of the expected baby or out of sympathy and not real love.

- Emotional breakdown: Separation of a couple might come about as a result of the premarital sexual encounter. Premarital sex and sex outside marriage destroy relationships. Those involved become miserable and disillusioned with life. Girls are the most frequent victims in this case. In most cases, young people do not know how to cope in such situations. Their hopes and dreams are shattered.

- Suicide: Loss of mutual trust and communication is harmful to a relationship. Fear and guilt (Ps 32) in the life of the one who is doing wrong brings about depression and can also lead to suicide.

- Sexually transmitted infections: The majority of young people involved in sex outside marriage are exposed to all sorts of sexually transmitted infections, such as syphilis, gonorrhoea, herpes, AIDS, etcetera. The prevalence of HIV and AIDS amongst cohabiting couples is on the increase. It should be noted that anyone who leads an unclean sex life runs the risk of catching these dreadful diseases. Indeed, graveyards have graves waiting to swallow the many young people dying from these terrible diseases (Smith 2004:223).

- Marriage breakdown: Sexual experiences from the past might even cause a breakdown in marriage when they haunt one of the partners. Sarah and John's case serves as an example in this regard. When Sarah was sleeping with her husband John, she burst into tears because she remembered her first sexual experiences with Edwin before she was married. She never enjoyed the sexual intimacy with her husband, because she was haunted by her past experiences of engaging in sexual activities with Edwin in her teens. Edwin had been so consumed by his pursuit of self-gratification that he had never cared how Sarah felt and responded when they engaged in their sexual encounters. Now, whenever she engages in a sexual encounter with her husband, those bad memories flash back. Consequently, her marriage is on the brink of collapsing.

- Wrath of God: Above all, those who engage in sex outside marriage need to note that what they are doing is against the will of God (Gn 39:9) and thereby they are inviting his wrath into their lives (Heb 12:5-6). It is a terrible thing to play in the hands of God: 'Therefore, since we are receiving a Kingdom that cannot be shaken, let us be thankful, and so worship God acceptably with reverence and awe, for our God is a consuming fire' (Heb 12:28-29).

\section{Biblical perspectives on human sexuality and implications for cohabitation and premarital sex} Biblical perspectives regarding human sexuality

One of the stories of creation, as outlined in Genesis, is the creation of human beings. Apart from the fact that human beings were created after the likeness of God, they were also created as sexual beings. Human sexuality should be seen as one of the beauties of God's created order, hence the need to guide our youth to an understanding of God's road map for human sexuality, to ensure that the sexual choices they make should bring glory to the Sovereign Lord. The intention of this section is to outline biblical principles regarding God's blueprint about human sexuality, which has direct bearing on the issue under reflection.

\section{Humanity originates from God}

According to the account in the first two chapters of Genesis, creation is attributed to the God. He created the universe and everything in heaven and on earth ex nihilo [out of nothing] and created order in everything. All of humanity is created by God and is from one blood. All of humanity is from the same forefather, Adam, the first man to be created by God (cf. Ac 17:26a). Humankind receives their life from God; consequently, their continued existence is dependent upon God. The beauty of the creation of humanity is that all are 
created in the imago Dei [image of God]. However, this image was distorted with the fall of humankind into sin. The fall has not only distorted their view about God and the world, but also their understanding of their sexuality.

\section{God designed human beings as sexual beings}

Another beauty of the creation of human beings is that they were created as sexual beings; as a result, sexuality should be seen as one of the human beauties (Wolters 1990:12). However, at the same time we need to understand that human sexuality is also very complex; it is more than just sex. It affects marriage, family, society and all that humankind is called to do. According to Olthuis (1976:7), a woman walks, talks, thinks, feels, loves, believes, writes, paints and buys as a woman and the same can be said about a man. Human sexuality reaches its highest levels through sexual encounters within the marriage context, which brings us to the next point.

\section{God designed sex to be enjoyed by husband and wife within the context of marriage}

The beauty of the creation of human beings also lies in the fact that God created sex for them to enjoy. Pleasure is very much part of human sexuality. It is only after Adam and Eve were joined together in marriage and the Lord had blessed them that he gave them the go-ahead to have sex and multiply. God's blueprint about marriage is well summed up in Genesis 2:24, which depicts marriage as an institution with three pillars. The three pillar imagery derives from three keywords outlined in Genesis 2:24, namely: leave, cleave and oneness. The three words follow logically after another and depict the kind of order expected when one wants to get married. You love your partner enough to want to be married to him or her and thereafter enjoy the oneness in marriage as you also consummate it by having sex. This blessing, that God gave Adam and Eve, came to be known in the history of the Christian church as a cultural mandate (Gn 1:28). The mandate entails the notion of being fruitful and multiplying and that man should subdue the world and reign on behalf of God or as instruments in the hands of God.

The normal practice, according to God's plan, is a heterosexual monogamous relationship, wherein sex is to be enjoyed within the marriage context. It is amazing to note that in the beginning, God did not create an identical twin brother for Adam. He created a woman instead, a suitable companion, a helpmate specifically designed to be complementary. Kimathi (1983:38-39) acknowledges that the two were biologically different, but equal before God and complementary to each other. The biological differences are also made manifest in different sexual organs, which complement each other well when engaging in the act of sex.

\section{God designed sex to be a beautiful expression of love}

When God designed sex, it was meant to be an expression of love between two people who are joined together in marriage. Those who exchange their vows, 'until death do us part', are also given the licence to share a blanket together. It is only in the marriage context that sex can be enjoyed without shame. This explains why a man leaves his father and mother and is joined to his wife and the two are united into one: 'Now although Adam and his wife were both naked, neither of them felt any shame' (Gn 2:24-25). Guilt and shame can only be felt by those who engage in sex outside the marriage context, it can be premarital or extramarital, it makes no difference. Marriage is the only place where the beauty of sex can be experienced as an expression of love between husband and wife. The Song of Solomon is an allegory of such an expression; it is full of tender, passionate love that is not dirty or embarrassing to the author. Husband and wife should commit themselves to this expression of love, hence the biblical injunction that, "The husband should not deprive his wife of sexual intimacy, which is her right as a married woman, nor should the wife deprive her husband' (1 Cor 7:3).

\section{God designed marriage for the two and only the two}

The fact that God created male and female and sanctioned their marriage in the beginning is a typical example that a truly Christian marriage is monogamous. That is why it is noted in Genesis 2:25 that the two shall become one flesh and should not be separated until death or until Christ comes for the second time. It is an undeniable fact that God instituted marriage as a union of one man and one woman; therefore, monogamy is the only form of marriage that meets the biblical norm. In the New Testament, both Christ and Paul indicated monogamy as normative (Mt 19:4-6, Eph 5:22-33, $1 \mathrm{Tm}$ 3:2); therefore the troth fellowship of marriage cannot be shared with more than one husband or wife in the full way that marriage demands (Olthuis 1976:23).

\section{Human beings should celebrate human sexuality}

Celebrating human sexuality entails the recognition that humankind is a unity and at the same time diverse; they were created male and female. It also entails getting married when you have the gift to do so and staying single if you are meant to be single. Paul saw the state of being single as a gift from the Lord that must be celebrated. According to him, the single life enabled him to devote himself more fully to the Lord's affairs (1 Cor 7:7-9), hence the need to maintain sexual purity. Married couples are instructed to enjoy their sexuality and make the most of it. Whenever people engage in sex outside marriage, they tarnish the image and character of God within them and within their partners.

\section{Human beings should honour God through their sexual choices}

The biblical prerogative is that human beings should honour God in whatever choices that they make in life (1 Cor 10:31), including sexual choices. The Bible condemns fornication (premarital sex), adultery, homosexuality (Lv 18:22) and the defilement of one's marriage vows by engaging in any or all of the above. The Bible encourages us to avoid all forms of sexual sin. Our bodies are meant to bring glory to God and not be defiled by sexual immorality. This truth is further entrenched in Hebrews: 
Marriage should be honoured by all and the marriage bed kept pure, for God will judge adulterer and all sexual immoral. Give honour to marriage and remain faithful to one another in marriage. God will surely judge people who are immoral and those who commit adultery.

(Heb 13:4)

\section{Implications for cohabitation and premarital sex}

The biblical principles mentioned previously have direct bearing on cohabitation and premarital sex and the following are some of those implications:

- Cohabitation and premarital sex are not justifiable morally or biblically. The biblical message says no to sex before marriage. The biblical words for fornication or sexual immorality refer to all sexual activity outside of marriage and the Scriptures clearly state that all such activity is forbidden (Lv 18, 20; Mt 15:19; 1 Cor 6:9-10,18). Christian young people who are engaged to get married therefore only have one option: they must either control their sexual drives or marry. Paul encourages Christians to get married when they can no longer bear to live without sex (1 Cor 7:36-37).

- Sex is a wonderful gift from God that should be enjoyed within the bonds of marriage (Gn 2:18-25). In African traditional culture, the bride's parents and the bridegroom's parents would come together. They would then agree on marriage terms for their children as well as lobola [the bride-price]. The marriage would then be formalised according to common law and the two would be considered husband and wife. Only after the rituals to unite were performed would they be allowed to have sex.

- The best marriage gift you can give to your future spouse is your virginity (Gn 24:16). This is one of the traditional values held in high esteem amongst African people. The virginity testing system amongst the Zulu-speaking people is a typical example. The gift of your virginity to your spouse is reason enough why you should wait until marriage. There is no doubt that a superior sexual relationship exists where the bonds of mutual communication, understanding, affection and trust have formed and where the two people have committed themselves to each other in a permanent relationship (Williams 2000:47).

- Premarital sexual experiences have great potential to destroy one's marriage. Past experiences can haunt one in such a way that when one is sleeping with one's spouse, past memories can come back to disturb one. Williams (2000:47) rightly noted that to spread intimacy around through a variety of sexual liaisons destroys the accumulated value of the previous relationship(s) and dilutes and scatters (in little doses to a number of people) what one has to give. The scars of sexual wounds of the past will manifest themselves in a negative way within the context of marriage.

\section{Towards a missional approach}

A missional church and Christian families should come to terms with the reality that African youth are in crisis because of the growing trend of cohabitation and premarital sex. Youth leaders, parents and the church as a whole should organise workshops, seminars and conferences to talk about these issues, lest our young people perish. Discussions should centre on what the Bible says about premarital sex and cohabitation. All stakeholders should proclaim clearly and unambiguously that according to Scriptures:

- Sex before marriage is a $\sin$ and is not permissible according to the Bible.

- God designed sex in such a way that it must be enjoyed and be fulfilled within the confines of a mutually faithful, monogamous relationship.

- Premarital sex and cohabitation amongst African youth is a matter of disobeying God and therefore, a call to repentance is the message that the church should propagate at such a time as this.

- Adequate sex education should be provided for our youth. This can be carried out through the medium of a family as an integrated part of society and a refuge to our children.

- It is about time that parents and churches give their children sex education from a Christian perspective, not just in what is best, but in what is right, a big resounding 'No!' to sex before marriage. Our youth should be taught to wait for marriage and let their sexuality blossom therein.

- If our youth are not able to control themselves, they must be reminded that marriage is an alternative that they can choose (1 Cor 7:36-37).

\section{Conclusion}

It is very clear from the foregoing that cohabitation and premarital sex are two trends that are on the rise and are becoming more socially acceptable, also in the South African context. They are practiced by Christian and non-Christian youth alike. Moving from a premise of engaging in such practices, which is not biblically justified, to what a missional Christian church can do, this article sought to bring down the numbers of those who cohabit and engage in premarital sex. It became clear from this research that cohabitation and premarital sex are contributing a great deal towards unwanted premarital pregnancies and the high prevalence of HIV and AIDS pandemic amongst the youth in South Africa, hence the need for serious intervention on the side a missional church. A missional church should look at all youth (Christian and non-Christian) who are cohabiting and engaging in premarital sex as a frontier that must be crossed. A missional church must first and foremost acknowledge that these practices cannot be morally and biblically justified, thus the need to reemphasise the respect that we must all give to the ancient wisdom of the church about monogamy as being crucial for our survival. Educational efforts to encourage the youth to wait for marriage before they start engaging in sex will go a long way in minimising premarital pregnancies and the spread of sexual transmitted infections, the HIV and AIDS pandemic included. This will also go a long way in saving the sinking image of marriage. 


\section{References}

Anderson, K., 2000, Marriage, Family and Sexuality: Probing the Headlines that impact your family, Kregel Publications, Grand Rapids, MI.

Chitamun, S. \& Finchilescu, G., 2003, 'Predicting the intention of South African female students to engage in premarital sexual relations: An application of the theory of reasoned action', South African Journal of Pschology 33(3), 154-161.

De Bruyn, P.J., 1993, The Ten Commandments, PU for CHE, Potchefstroom.

Dolbik-Vorobei, T.A., 2005, 'What College students think about problems of marriage and having children', Russian Education society 47(6), 47-57.

Gustafsson, S. \& Worku, S.Y., 2006, 'Marriage markets and single motherhood in South Africa', Tinbergen Institute Discussion Paper, viewed 11 November 2008, from http://www.tibergen.nl/discussionpapers/06102.pdf

Hosegood, V., McGrath, N. \& Moultrie, T., 2009, 'Dispensing with marriage: Marital and partnership trends in rural KwaZulu-Natal, South Africa 2000-2006', Demographic Research, 20(13), 279-312, viewed 26 May 2009, from http://www.demographicresearch.org/Volumes/Vol20/13/

Kimathi, G., 1983, Courting in Marriage, Uzima Press, Nairobi.

Manning, W.D., Longmore, M.A. \& Giordano, P.C., 2007, 'The Changing Institution of Marriage: Adolescents' expectations to cohabit and to marry', Journal of Marriage \& Family 69(3), 559-575. doi:10.1111/j.1741-3737.2007.00392.x

Mashau, T.D., 2006, Unlocking the Mystery of Marriage: Issues in premarital counselling, Potchefstroom Theological Publications, Potchefstroom.

Mashau, T.D., 2008, God's road map for human sexuality: Discipling your child to make sexual choices that honour God, AcadSA, Kempton Park.

Murray-Swank, N.A., 2005, 'At the crossroads of sexuality and spirituality: The sanctification of sex by College students', The International Journal for the Psychology of religion 15(3), 199-219. doi:10.1207/s15327582ijpr1503_2
Musick, K., 2007, 'Cohabitation, non-marital childbearing, and the marriage process' Demographic Research 16(9), 249-286, viewed 11 November 2008, from http:// www.demographic-research.org/Volumes/Vol16/9/

Mwaba, K. \& Naidoo, P., 2005, 'Sexual practices, attitudes toward premarital sex and condom use among a sample of South African university Students', Socia Behaviour and Personality: An International Journal 33(7), 651-656. doi:10.2224/ sbp.2005.33.7.651

Ndungane, N., 2003, A World with a Human Face: A Voice from Africa, WCC Publications, Geneva.

Olthuis, J.H., 1976, I Pledge You My Troth: a Christian View of Marriage, Family, Friendship, Harper \& Row, New York.

Parry, M.L., 1981, Cohabitation: Social work and Law, Sweet and Maxwell, London.

Scherrer, D.L. \& Klepacki, L.M., 2004, How to talk to your kids about sexuality, Nexgen, Colorado.

Schwellnus, T., 1994, 'The Legal Implications of Cohabitation in South Africa - a Comparative Approach', PhD Thesis, Rijksuniversiteit te Leiden.

Smith, D.J., 2004, 'Premarital sex, procreation, and HIV risk in Nigeria', Studies in Family Planning 35(4), 223-235. doi:10.1111/j.0039-3665.2004.00027.x PMid:15628781

Stern, O., 2006, Co-habitation and the law, viewed 23 November 2007, from http:// www.mallinicks.co.za/print_publications_text.asp?id=51

Thatcher, A., 1999, Marriage after Modernity: Christian Marriage in Postmodern Times, Sheffield Academic Press, London.

Van der Merwe, C.G. \& Du Plessis, J.E., 2004, Introduction to the law of South Africa, Kluwer Law International, The Hague, The Netherlands.

Williams, J., 2000, 'Probing the Headlines That Impact Your Family', in K. Anderson (ed.), Marriage, Family and Sexuality, pp. 46-55, Kregel Publications, Grand Rapids, MI.

Wolters, A.M., 1990, Creation Regained: Biblical basics for a reformational worldview Eerdmans, Grand Rapids, MI. 